\title{
Suspected chromosomally integrated human herpes virus 6 in hematopoietic stem cell transplantation
}

\author{
Anna Todisco, ${ }^{1}$ Maria Landi, ${ }^{1}$ Beatrice Paola Festa, ${ }^{1}$ Lidia Santoro, ${ }^{2}$ Gabriella Storti, ${ }^{2}$ \\ Giulia Campanini, ${ }^{3}$ Raffaele Ariola, ${ }^{1}$ Franca Romeo, ${ }^{1}$ Generoso Violano' \\ ${ }^{1}$ Virology Unit, Department of Laboratory Medicine, San Giuseppe Moscati Hospital, Avellino; \\ ${ }^{2}$ Haematology and Transplantation Unit, Department of Onco-haematology, San Giuseppe Moscati \\ Hospital, Avellino; ${ }^{3}$ Molecular Virology Unit, Department of Microbiology and Virology, San \\ Matteo Policlinic Foundation, Pavia, Italy
}

\begin{abstract}
Summary
Background and aims: We report a case of a 27 -year-old male affected by acute myeloid leukaemia MLL-PTD positive. After autologous stem cell transplantation, he was monitored based on cytomegalovirus, Epstein-Barr virus and human herpes virus 6 (HHV-6) DNA quantification in blood. Relapse occurred one year after transplantation; then the patient underwent to allogenic bone marrow transplantation using genotypically HLA-identical donor (sister). HHV-6 DNAemia was positive and persistently elevated, either after autologous either after allogenic transplant suggesting the occurrence of HHV-6 chromosomally integration. The work aim is to prove the occurrence of chromosomally integrated-HHV-6 (ci-HHV-6).

Materials and Methods: HHV-6 DNA extraction was performed by automated extractor and DNA was amplified-quantified by Real Time polymerase chain reaction. Species identification was performed by sequencing HHV6-U100 glycoprotein using automated sequencer and sequencing products were analysed using the Blast program.
\end{abstract}

Correspondence: Anna Todisco, U.O.C. Virologia, AORN San Giuseppe
Moscati, Contrada Amoretta 83100 Avellino, Italy.
Tel./Fax: +39.082.520.3759.
E-mail: antodisco@aosgmoscati.av.it
Key words: Human herpes virus 6; DNA; integration; hematopoietic stem cell
transplantation.

Contributions: the authors contributed equally.

Conflict of interest: the authors contributed equally.

Received for publication: 17 July 2014.

Revision received: 4 February 2016.

Accepted for publication: 6 February 2016.

(C) Copyright A. Todisco et al., 2016

Licensee PAGEPress, Italy

Microbiologia Medica 2016; 31:4590

doi:10.4081/mm.2016.4590

This article is distributed under the terms of the Creative Commons Attribution Noncommercial License (by-nc 4.0) which permits any noncommercial use, distribution, and reproduction in any medium, provided the original author(s) and source are credited.
Results: After autologous transplantation HHV6-DNAemia was 5.4 $\log$ copies/mL setting to $3.9 \log$ copies/mL for a long period post allogenic transplantation. The patient's hair follicles were tested for HHV6 DNA having positive results. Sequences of both strains of HHV6 extracts from blood and hair follicles resulted species B. HHV6 viral load decreased significantly after Lymphocyte Infusion by ci-HHV6 negative donor (sister), having steady viral load during the following six months of monitoring. One year later, patient is in complete haematological remission.

Conclusions: Detection of HHV-6 in hair follicles and HHV-6 DNAemia persistently elevated before allogenic transplant, confirm the occurrence of ci-HHV-6. The observed important decreasing viral load is potentially due to the successful engraftment of ci-HHV-6-negative donor marrow after allogeneic transplant.

\section{Introduction}

Human herpes virus 6 (HHV-6) is a ubiquitous $\beta$-herpes virus recently classified into two different species: $\mathrm{HHV}-6 \mathrm{~A}$ and $\mathrm{HHV}-6 \mathrm{~B}$ (1). In immunocompetent individuals, HHV-6B is the cause of the common childhood illness (exanthema subitum); HHV-6 infections, especially from HHV-6B species, have been associated with morbidity after hematopoietic stem cell transplantation (HSCT), especially with delayed monocyte and platelet engraftment (5), encephalitis, fever (12) and rash (10). In most of infected people, HHV-6 has been found to persist throughout life and subsequently reactivate; HHV-6 is the only human herpes virus found integrated into host chromosomes persisting in latent state, a condition called chromosomally integrated human herpes virus 6 (ci-HHV-6) (7). Complete HHV-6 genome is integrated into the telomere of human chromosomes (6). Since HHV-6 can infect and integrate into germ cells, ci-HHV-6 can be inherited in a Mendelian manner, with a $50 \%$ chance of being passed to a child. Moreover, because of its presence into DNA of germ cells, at least one copies of HHV-6 is present in every nucleated cell of the body, from PBMCs to hair follicles (5). The mean HHV-6 DNA concentration in blood of individuals with ci-HHV-6 is $5.5 \mathrm{log}$ copies/mL of whole blood and the DNAemia is persistently high (11). The demonstration of the presence of integrated HHV-6 can be achieved by DNA PCR testing of hair follicles or nails for the presence of $>1$ copies/hair follicle (2). Several studies suggest that ciHHV-6 transplant patients may be more likely to experience GVHD and bacterial infections (4). 


\section{Case Report}

We report a case of a 27 years old male affected by acute myeloid leukaemia $M L L-P T D$ positive (mixed-lineage leukaemia-partial tandem duplications). In 2009 he underwent autologous stem cell transplantation, showing delayed engraftment. Relapse occurred one year after transplant; the patient was treated by allogeneic bone marrow transplantation after high-dose chemotherapy using genotypically HLA-identical donor (sister). 10 months later a second relapse was treated by chemotherapy followed by Donor lymphocyte infusion (DLI). The present study was carried out during hematologic remission.

The patient was monitored based on cytomegalovirus (CMV), Epstein-Barr virus (EBV) and HHV-6 DNA quantifications in blood after allogeneic transplantation. We never observed reactivation of CMV neither of EBV. The patient had persistently high levels of circulating HHV6 DNAemia, $5.4 \log$ copies/mL, after autologous stem cell transplantation; the suspect of ci-HHV-6 led us to perform hair follicles analysis. DNA PCR testing of hair follicles resulted positive for the presence of HHV-6 DNA. It was performed gene sequencing U100 strains of HHV-6 extracts from blood and hair follicles. Sequences resulted perfectly stackable and relieved HHV-6 species B.

\section{Results and Discussion}

HHV-6 viral load was performed by QIAcube automated DNA extraction, using QIAmp DNA Mini Kit (QIAGEN, Hilden, Germany). Isolated DNA was amplified and quantified by Real Time PCR using Q-HHV6 Real Time Alert Kit (Elitechgroup Spa, Turin, Italy) based on TaqMan ${ }^{\circledR}$ chemistry, using 7500 Fast Dx Instrument (Life Technologies Carlsbad, CA, USA). Genomic DNA extraction was performed incubating overnight 10 hair follicles at $56^{\circ} \mathrm{C}$ with $180 \mu \mathrm{L}$ ATL Buffer (QIAGEN) and $20 \mu \mathrm{L}$ proteinase $\mathrm{K}$, followed by QIAcube automated DNA extraction, using QIAmp DNA miniKit selecting protocol Tissue. Of a final volume $=200 \mu \mathrm{L}, 5 \mu \mathrm{L}$ were amplified by real time PCR. Nested RT-PCR was used to amplify glycoprotein U100 of HHV-6. To identify species after DNA extraction from whole blood and hair follicles, two rounds of PCR were performed using the primers sets from Norton et al. (8). Amplified products were separated by agarose gel electrophoresis, stained with ethidium bromide and visualized using UV light in the Gel Doc 2000 (Bio-Rad, Hercules, CA, USA). BigDye Terminator Cycle Sequencing Kit (Perkin-Elmer Applied Biosystems, Foster City, CA, USA) was used to sequencing PCR products by using ABI3130xl Genetic Analyser automated sequencer (Applied Biosystems). 898 nucleotides sequencing products were analysed using the Blast program (http://blast.ncbi.nlm.nih.gov).

After autologous stem-cell transplantation, HHV-6 DNAemia resulted $5.4 \log$ copies/mL and was persistently $>8000$ copies/mL $(\log 3.9)$ (Figure 1), being between 8500 and 23000 copies/mL, for a long period post allogenic transplantation (July 2010 to May 2011). During the fifth week he developed peak viraemia and was treated with ganciclovir, achieving just a moderate viraemia reduction. In April 2011 a relapse occurred and was treated with azacitidin in combination with DLI; at $46^{\text {th }}$ week, in may he was treated with ganciclovir achieving again just a moderate HHV-6 viraemia reduction (median viral load 4550 copies $/ \mathrm{mL}$ ). In September, after the finding of bone marrow blast cell ratio $>50 \%$, salvage chemotherapy called FLANG was initiated obtaining complete haematological remission with a recovery of donor chimerism. In January 2012, and again in February, during haematological remission he received DLI after that occurred moderate graftversus-host-disease with skin and liver involvement. HHV-6 viral load decreased to $<556$ copies/mL (lower limit of linearity) whole blood, having steady viral load during the following six months of monitoring.

A year later, patient is in complete haematological remission, showing in August HHV-6 steady viral load $<556$ copies/mL whole blood.

Viral load results suspicious for ci-HHV-6, lead to conduct DNA PCR testing of hair follicles. Qualitative Real Time PCR results tested positive for the presence of HHV-6 DNA, with comparable value of Beta-globin cycle threshold (26.9 and 27.88 respectively), meaning $\geq 1$ HHV-6 copies/cell.

HHV6 DNAemia performed on donor was negative.

Nucleotides sequencing products analysed from whole blood and hair follicles revealed a 99\% identity with the HHV-6B HST strain (AB021506.1) and HHV-6B Z29 strain (AF157706.1).

\section{Conclusions}

Detection of HHV-6B in hair follicles obtained from the patient and HHV-6 viral load persistently elevated (5.4 log copies/mL whole blood)

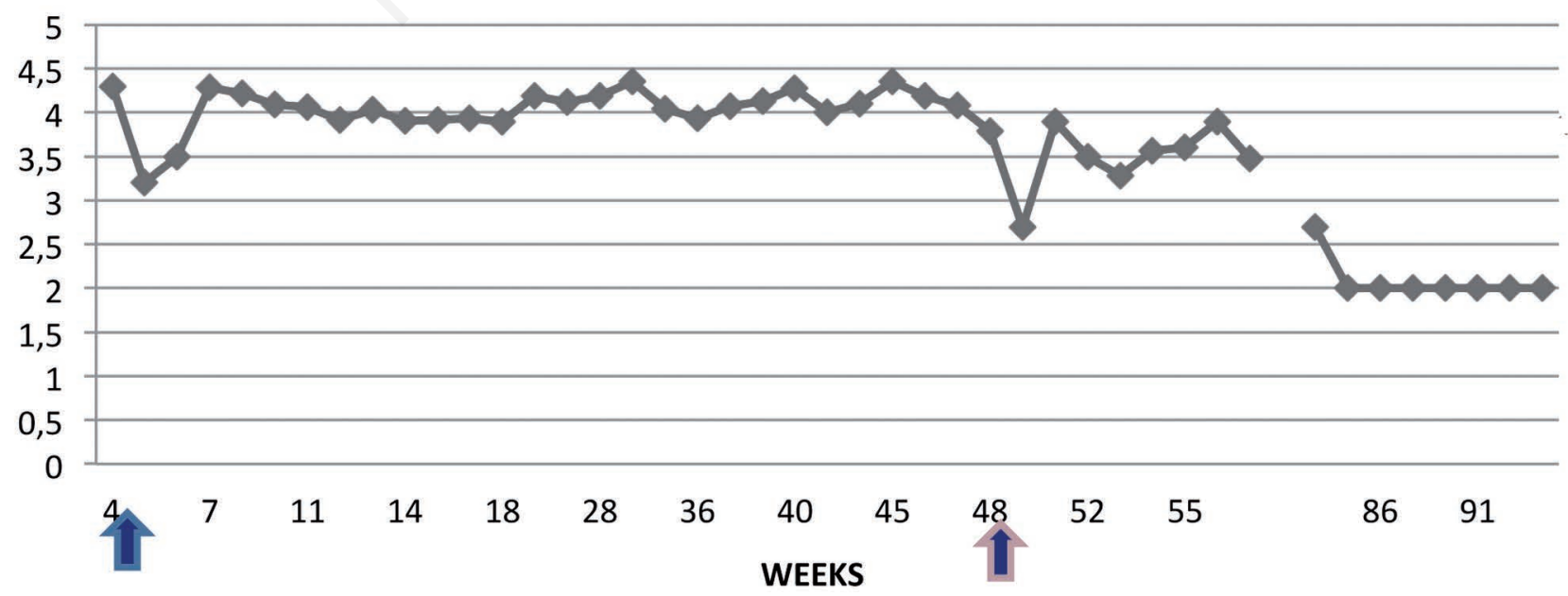

Figure 1. Monitoring the human herpes virus 6 load (weeks after hematopoietic stem cell transplantation) in whole blood (copies/mL). 
before allogenic transplant, confirm the occurrence of ci-HHV-6. Level of viral load after allogeneic bone marrow transplantation decreased consistently, $3.9 \log / 4.36 \log$ copies/mL, and, even if case of viraemia peak, no longer reached high viral load suggestive of ci-HHV-6 $(10,6,3)$. The observed further decreasing viral load is potentially due to the successful engraftment of ci-HHV-6-negative donor marrow after DLI administration performed in 2012.

Further studies are needed to clarify if a correlation does exist between virus reactivations and frequent relapses, and between ciHHV-6 and GVHD.

\section{References}

1. Ablashi D, Agut H, Alvarez-Lafuente R, et al. Classification of HHV-6A and HHV-6B as distinct viruses. Arch Virol 2014;159: 863-70.

2. Clark DA, Nacheva EP, Leong HN, et al Transmission of integrated human herpesvirus 6 through stem cell transplantation: implications for laboratory diagnosis. J Infect Dis 2006;193:912-6.

3. Hubacek P, Virgili A, Ward KN, et al. HHV6 DNA throughout the tissues of two stem cell transplant patients with chromosomally integrated HHV 6 and fatal pneumonitis. BJH 2009;145:394-8.

4. Lee SO, Brown RA, Razonable RR. Clinical significance of pretrans- plant chromosomally integrated human herpesvirus 6 in liver transplant recipients. Transplantation 2011;92:224-9.

5. Ljungman P, Wang FZ, Clark DA, et al. High levels of human herpesvirus 6 DNA in peripheral blood leucocytes are correlated to platelet engrafment and disease in allogenic stem cell transplant patients. Br J Haematol 2000;111:774-8.

6. Luppi M, Barozzi P, Bosco R, et al. Human herpesvirus 6 latency characterized by high viral load: chromosomal integration in many, but not all, cells. J Infect Dis 2006;194:1020-1.

7. Luppi M, Marasca R, Barozzi P, et al. Three cases of human herpesvirus 6 latent infection: integration of viral genome in peripheral blood mononuclear cell DNA. J Med Virol 1993;40:44-52.

8. Norton RA, Caserta MT, Hall CB, et al. Detection of human herpes virus 6 by reverse transcription-PCR. J Clin Microbiol 1999;37:3672-5.

9. Pellet PE, Ablashi PV, Ambros PF, et al. Chromosomally integrated human herpesvirus 6: questions and answers. Rev Med Virol 2012;22:144-55.

10. Sashihara J, Tanaka-Taya K, Tanaka S, et al. High incidence of human herpesvirus 6 infection with a high viral load in cord blood stem cell transplant recipents. Blood 2002;100:2005-11.

11. Ward KN, Leong HN, Nacheva EP, et al. Human herpesvirus 6 chromosomal integration in immunocompetent patients results in high levels of viral DNA in blood, sera and hair follicles. J Clin Microbiol 2006;44:1571-4.

12. Zerr DM. Human herpesvirus 6 and central nervous system disease in hematopoietic cell transplantation. J Clin Microbiol 2006;37:552-6. 